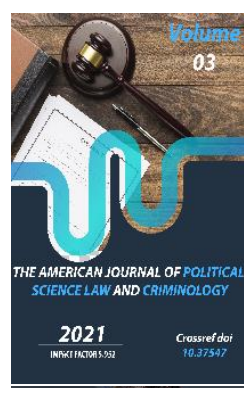

\title{
Issues Of Improving The Institution Of Crime
}

\author{
Ahror Sharipov \\ Student, Tashkent State University Of Law, Tashkent, Uzbekistan
}

Copyright: Original

content from this work

may be used under the

terms of the creative

commons attributes

4.0 licence.

\section{ABSTRACT}

This article examines the concept, nature and specifics of criminal involvement. Also, some problems in the legal norms of the institute of criminal involvement were analyzed, and on the basis of these analyzes, proposals and scientific recommendations were developed.

\section{KEYWORDS}

Involvement in crime, criminal law, participation, improvement, criminal law.

\section{INTRODUCTION}

Radical reforms in the Republic of Uzbekistan along with the criminal law is also constantly improving. But that's it however, the criminal law does not eliminate the pending problems. Among such problems, the institute of criminal involvement plays an important role takes over. After all, the institute of criminal involvement is a tool of criminal law is particularly important in the prevention of crime through. The full use of the potential of 
this institution will significantly contribute to the rapid and complete detection of crimes that are being prepared, committed or are being committed, and, in essence, the prevention of crime.

\section{THE MAIN RESULTS AND FINDINGS}

In turn, this is currently the case in scientific studies devoted to a comprehensive analysis of the institute of criminal involvement a number on improving the legal mechanism of the institute suggestions developed. On improving the criminal law the main directions of these proposals are, first of all, its General part and secondly, the Special part. In particular, A.V.Zarubin[1] and Ponomarenko[2], arguing that the General Part of the Criminal Code should define the concept and forms of criminality, propose to define the concept and forms of criminal liability as "Liability for criminal involvement" in a single norm of the General Part.

The first part of this norm deals with the concept of the institution of criminality and crimes related to criminality the basis for determining liability (for involvement in a crime) liability is provided for in the articles of the Special Part of the Criminal Code); the second (concealment of a crime), the third (admission of a crime), and the fourth (nonreporting of a crime) to explain the concepts and signs of forms of involvement in a crime is dedicated.

However, neither A.A. Otajonov[3] nor such a legal regulation of the institute of criminal involvement can have a positive effect on the full use of the potential of this institution and the elimination of existing problems in judicial practice. Because, firstly, the effectiveness of a complex legal regulation of the institution of criminality in a single norm is not high, then the norm can be expressed in a very broad and complex way (which complicates the understanding of the essence of this institution), secondly, the norm recommended by scientists (determination of the list of persons not liable for involvement in the crime, what category of crimes the failure to report the crime is committed, etc.). we agree.

In order to further increase the effectiveness of this institution, the correct assessment of the act and increase the measures of criminal justice, it is necessary to improve the institution of criminal justice, taking into account modern conditions. Therefore, our laws should prohibit the use of terms that may cause some problems in terms of content.

In order to improve this institution, A.A.Otajonov [4] argues that it would be logical to use the term "offender" instead of the term "criminal" in the development of involvement in crime and other related norms.

In turn, for acts related to involvement in a crime the problem of defining responsibilities and placing them in the Special Part of the Criminal Code is an important issue in theory and practice forms.

In this sense, for the involvement of scientists in crime take into account the views expressed on the determination of responsibility deserves. "It should be noted that N.S.Kosyakova and A.D.Makarovs believed that the responsibility for acts related to a crime should be reflected in the "Crimes against Public Security and Public Order" section of the Special Part, which should only provide for liability for failure to report a crime 
and concealment of a crime. A.V.Zarubin and E.V. Ponomarenko, on the contrary, suggested that for all forms of involvement in a crime, the norms of the Special Part provide for liability, all of which should be defined in the chapter "Crimes against Justice" [5].

In this regard, in determining the criminal liability for crimes related to criminal involvement in the Special Part of the Criminal Code, we must first take into account its object and, secondly, pay attention to the development of norms that serve to increase the efficiency of the institution.

It is known that the current criminal law provides for liability for forms of criminal involvement in various sections and chapters of the Special Part. For example, liability for a crime is defined in Article 208 of the Criminal Code as an integral part of the "inaction of the authorities". Indeed, the logical requirements in this article are violated in the case of mixing two ideologically and legally unrelated legal phenomena in violation of the rules of legislative technique sent For this reason, the inaction of the authorities and the admission of crime a special liability measure need.

\section{CONCLUSION}

About crime, which is a separate form of involvement in crime in our opinion, the provision of liability in one article of the Special Part of the Criminal Code for failure to report and conceal a crime violates the logical requirements of the structure of the norm of criminal law and legally contradict each other in accordance with the rules of legislative technique the interference of two unrelated legal events and the individualization of liability for these acts may complicate the possibilities.
Also, the analysis of the criminal law of foreign countries and the results of the study showed that the provision of liability in the Special Part of the Criminal Code for failure to report or conceal a crime does not rule out the possibility of positive results.

\section{REFERENCES}

1. Zarubin A. V. Criminal legal regulation of involvement in crime: Author's abstract. dis ... cand. jurid. sciences. Krasnoyarsk, 2004 .-- P. 5.

2. Ponomarenko E. V. Some theoretical and legislative problems of involvement in crime in the criminal law of the Russian Federation: Avtoref. dis ... cand. jurid. sciences. - Saratov, 2007 --- P. 6.

3. Otajonov A.A. Involvement in crime: criminal law and criminological aspects. jurid... fan. jurid. nom ... diss T .: 2009. - p. 129.

4. Otajonov A.A. Involvement in crime: criminal law and criminological aspects. jurid... fan. jurid. nom ... diss T .: 2009. - p. 131.

5. Zarubin A. V. Criminal legal regulation of involvement in crime: Author's abstract. dis ... cand. jurid. sciences. Krasnoyarsk, 2004. - pp. 10-12, Ponomarenko EV Some theoretical and legislative problems of involvement in crime in the criminal law of the Russian Federation: Author's abstract. dis ... cand. jurid. sciences. - Saratov, 2007 .-P. 9.

6. Уразалиев М. К. ЕТКАЗИЛГАН ЗАРАР ҚОПЛАНГАНДА ЖАВОБГАРЛИКДАН ОЗОД ҚИЛИШНИНГ ХУСУСИЯТЛАРИ //ЖУРНАЛ

ПРАВОВЫХ 


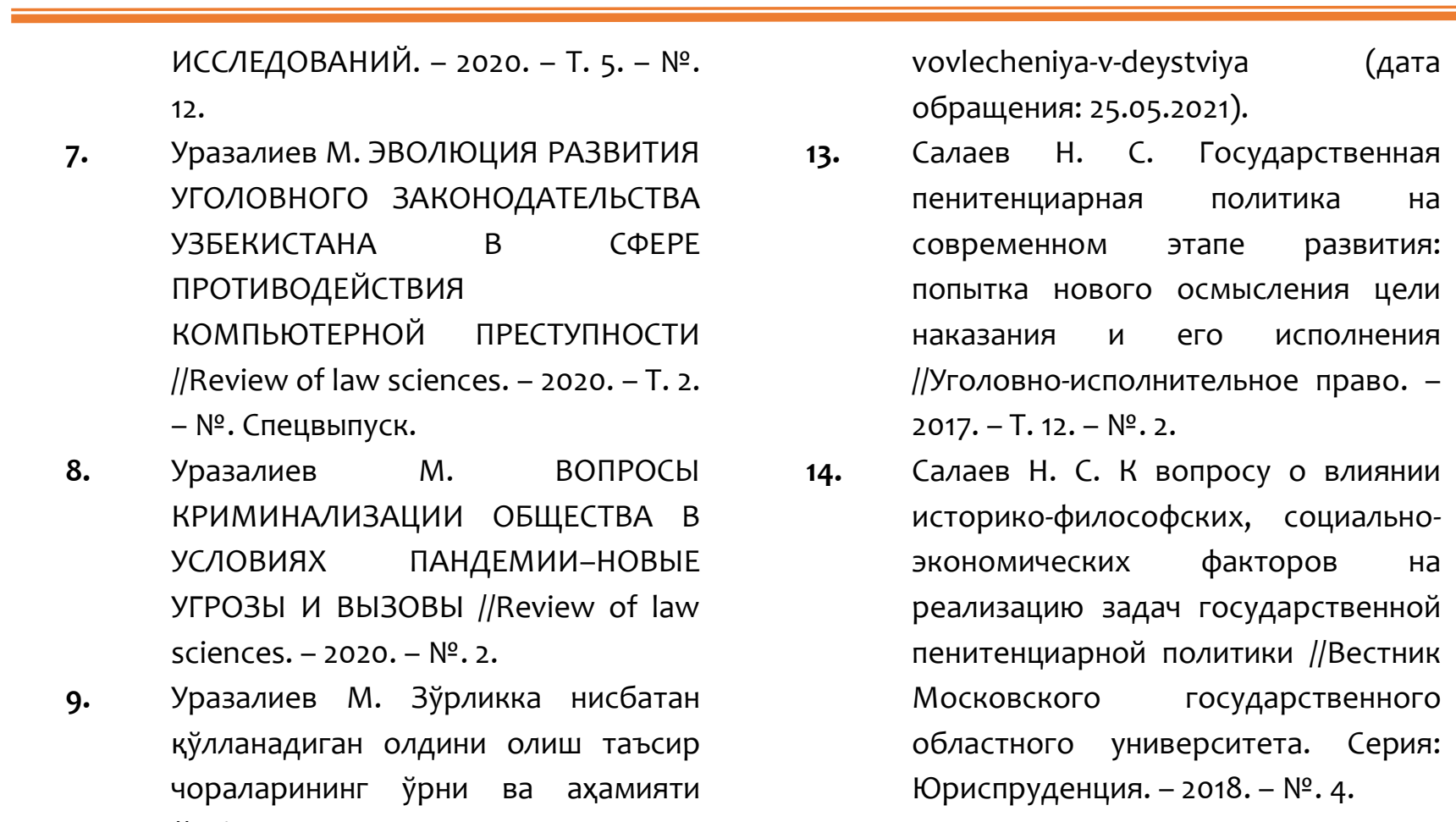

//Общество и инновации. - 2020. - Т. 2. - №. 1/S. - C. 236-243.

10. Уразалиев М. Мажбурий ижро тизимини такомиллатириш-суд-хуқуқ сохасидаги устувор вазифа //Общество и инновации. - 2021. - Т. 2. - №. 1. - С. 37-43.

11. Allanova A. A., Kaustav C. A Comparative Study Of The Economic Crime In Uzbekistan And India: A Critical Analysis //The American Journal of Political Science Law and Criminology. - 2021. - T. 3. - №. 04. - C. 73-78.

12. Алланова Азиза Антисоциальное поведение несовершеннолетнего объективный признак преступления в виде вовлечения в действия // Review of law sciences. 2020. №Спецвыпуск. URL: https://cyberleninka.ru/article/n/antiso tsialnoe-povedenienesovershennoletnego-obektivnyypriznak-prestupleniya-v-vide- 